\title{
Comparison between different solar cooling thermally driven system solutions for an office building in Mediterranean Area
}

\author{
Furio Cascetta ${ }^{1}$, Cuca Cirillo $^{1}$, Alessandro Della Corte ${ }^{1}$, Sergio Nardini ${ }^{1,2^{*}}$ \\ ${ }^{1}$ Dipartimento di Ingegneria Industriale dell'Informazione, Università degli Studi della Campania \\ "Luigi Vanvitelli", Via Roma 29, 81031 Aversa (CE), Italy \\ ${ }^{2}$ Sun Energy Europe S.r.l., Academic Spin-Off, Via B. De Capua 26, 81043 Capua (CE), Italy
}

Email: sergio.nardini@unina2.it

\begin{abstract}
The amount of energy for air conditioning in the summer time in Mediterranean Area is very high because of hot weather and high temperature values. Solar cooling technology is interesting because strong sunlight covers the cooling requirement. The heat energy from the sun it is available when the demand of electricity has high peaks for the strong use for air conditioning devices. In this work, an analysis by means of NEGST software (New Generation of Solar Thermal System) on a solar cooling and heating system located in the southern part of Italy has been carried out. The building is a Quality Assurance Office of a chemical industry. It is $48 \mathrm{~m}$ long, $23 \mathrm{~m}$ wide and $3.5 \mathrm{~m}$ high, and about 200 people work inside. Thermal loads from people, PC, machines etc. have been estimated by means of Energy Plus code. Three different type of collectors (FPC, ETC and PTC) and two different chillers have been considered: single effect for collectors FPC and ETC and double effect $\left(\mathrm{H}_{2} \mathrm{O}-\mathrm{BrLi}\right)$ for the collectors PTC. Results in terms of solar fraction and PE-Saving for three different configurations are shown. Besides, the payback period for the best configuration is estimated.
\end{abstract}

Keywords: Economic Analysis, Simulation, Solar Collector, Solar Heating and Cooling, Sorption Cooling.

\section{INTRODUCTION}

Solar energy for residential and industrial sectors remains the best technology in air conditioning and refrigeration; it is environmentally-friendly solution since the system uses thermal energy to produce cold and this allows the use of solar thermal energy, waste heat and other sources of low enthalpy heat. Recently, absorption cycles are commercially available in large amount, based on double and also triple effect cycles typologies.

There are other needs that solar thermal systems can be offer as domestic hot water and space heating [1,2].

Solar cooling and heating is a suitable option to reduce the electricity and fossil fuels demand as well as the importation of energy [3].

Many studies were carried out on solar energy, in particular with assisted absorption chillers.

Commonly, $\mathrm{LiBr}-\mathrm{H}_{2} \mathrm{O}$ has used as working fluids for solar absorption systems. Researches, involving simulation analysis and experimental research, were reported in [4-11].

Mazloumi et al. [4], designed a solar cooling system for a residential building. They defined solar field with Parabolic Trough Collector (PTC) and a single-effect absorption chiller in order to meet the thermal energy demand of a house. Their results showed that the collector mass flow rate allows a minimal effect on the minimum required collector area and a good effect on the optimal capacity of the heat storage. A simulation and fine-tuning of a solar absorption cooling system with Evacuated Tube Collectors (ETC) was carried out by Assilzadeh et al. [5]. The system was designed for tropical regions as Malaysia and others. They considered that the system was to operate continuously to make it more fruitful, it was determined a storage tank of $0.8 \mathrm{~m}^{3}$ and a solar field of $35 \mathrm{~m}^{2}$ of ETC collectors with a slope of $20^{\circ}$. Evola et al. [11] studied the performance of an air conditioning system based on a low capacity water-cooled $\mathrm{LiBr}$ /water absorption chiller, with the aim to identify the role of the main operating conditions. The analysis was carried out in dynamic conditions, based on a general model already validated through experimental data. The comparison with a conventional air-cooled vapour compression chiller provided interesting advice for an effective exploitation of the absorption technology in residential applications. Luna [12] carried out an analysis of innovative technology that permits heating, cooling and hot water for residential house, set in Mexicali, Mexico. They defined a solar field of $104 \mathrm{~m}^{2}, 6 \mathrm{~m}^{3}$ the storage tank and the best temperature set point of $75^{\circ} \mathrm{C}$ of the auxiliary boiler. Their results showed that the reduction of emissions is $9.0 \mathrm{t}_{\mathrm{CO} 2}$ per year with respect to a vapor compression cooling system.

Florides et al. [13] designed a SACS with weather conditions in Nicosia, Cyprus. They defined the best 
configuration: $15 \mathrm{~m}^{2}$ of PTC collectors, a $0.6 \mathrm{~m}^{3}$ hot water storage tank and a $\mathrm{LiBr}-\mathrm{H}_{2} \mathrm{O}$ as working fluid to meet the thermal load during the year. In the world, the higher percentage of the solar absorption chillers are designed with single effect chillers and low temperature solar thermal flat plate or evacuated tube collectors (FPC and ETC) $[14,15]$. Downside it is the lower COP's value, in fact, to meet the thermal energy demand it is need of a high collector area. Commonly many rooftop areas are not sufficient to install many solar collectors, or many solar collectors can be too expensive. Said et al. [16] accomplished a mathematical analysis on a solar cooling system with single effect absorption chiller system, evaluating the global chiller's COP To verify the reliability of the mathematical model they made up an experimental plant testing it for two days. Their results defined an improvement in the chiller's COP by $10 \%$ using the dephlegmator heat recovery and by $8 \%$ using the refrigerant storage unit. In the work of Balghouthi et al. [17] a SCS (Solar Cooling System) with single effect chillers was studied. They carried out an analysis by varying many features as tank capacity, collector area and collector slope. Their results showed the best configurations for reliable operation of the system. Reda et al. [18] worked on energetic performance of solar cooling thermally driven system configurations for a building in a Nordic country. They studied two cases, differing for the hot storage tank connection. In the case 1 the chiller was provided by tank, while the case 2, the tank supplied the chiller but also the solar collectors supplied the chiller directly. Their results showed that case 2 had the best energetic performance, because of the versatility shown in summer. Shirazi et al. [19] accomplished a feasibility study of a solar cooling system with single effect, double effect and triple effect absorption chillers for heating and cooling applications. Their results demonstrated that by using concentrating collector with multi effect chillers over solar single effect chillers in climates with low direct normal irradiance level there were not advantages. PTC collectors and solar multiple effect chiller are used in climates with direct normal irradiance fractions above $60 \%$ because it is necessary that the solar field is small. Al-Alili et al. [20] evaluated the performance in a hot climate as Abu Dhabi of a solar cooling system with single effect absorption chiller. They demonstrated that the electrical energy consumed is $47 \%$ less than the conventional vapor compression cycles, besides their results showed that the collector area have a predominant impact on the payback time in terms of economic performance. Mammoli et al. [21], focused on the energetic performance of the solar single effect absorption chiller following different control strategies throughout the year. Their results showed that if the hot water storage tank was well insulated, the solar fraction could be boosted by $60 \%$. Eicker et al. [22-24] analyzed a solar cooling system in different climates, they focused on economic and energetic performance, showing that it is possible to reduce the primary energy of $40-70 \%$ and the system design and energetic load had important roles in the performance of the system. Cucumo et al. [25] carried out a thermodynamic analysis and evaluation of the performance of solar plants with parabolic trough collectors cooled by atmospheric air. The plants were studied in two operating modes: at variable flow rate and constant temperature at the outlet collectors, and at constant flow rate and variable outlet temperature. The results obtained demonstrated a very good performance by this type of plant, which utilizes the ambient air in place of the expensive and more problematic fluids such as synthetic oils and molten salts used in already constructed plants. It is very simple from the constructional point of view and does not need any water because the working fluid in the engine is the air and the intercooling of the compressor can be also done by atmospheric air. Regue et al. [26], in their study tried to minimize losses in order to increase the performance of a solar thermal concentrator. They carried out an experimental analysis, which consisted of converting solar radiation into thermal energy using a cylindrical parabolic solar concentrator. The developed theoretical model involved a number of parameters such as the average monthly solar radiation that allowed estimating the direct radiation at the reflector, the geometrical concentration and exchange of heat between the opening of the collector and the receiver, allowed the evaluation of the temperature at the latter. This model of concentration led to temperature levels between $70 \mathrm{C}^{\circ}$ to $200 \mathrm{C}^{\circ}$. Drosou et al. [27] showed that the use of concentrating solar collectors led to significantly higher output temperatures that could enable the use of two stage absorption chillers with a higher COP. Alternatively, when low or medium temperature heat was required, the use of CST systems took less space to cope with it than traditional flat plate collectors. The combination of these parameters can contribute to removing key barriers associated with the broader diffusion of solar cooling technology, enhancing the potential to become more competitive to the conventional air conditioning technologies. Recently, Sibilio et al. [28] presented a study on a SHC system composed of a flat-plate solar collector array, a hot water storage tank, a single-effect $\mathrm{LiBr}-\mathrm{H}_{2} \mathrm{O}$ absorption chiller, a cold water tank, a cooling tower and an auxiliary gas-fired boiler. The SHC system was designed and modelled to satisfy the requirements for space heating, domestic hot water as well as space cooling. The performance of the solar heating and cooling system were analyzed upon varying, solar collectors area, size of both the hot water tank and cold water tank capacity. Finally, the performance of the optimized SHC system was compared with that associated to a conventional system composed of a natural gas-fired boiler and an aircooled water chiller fed by the national electric grid.

In this work, a feasibility study of a solar cooling thermally driven for a building in Mediterranean area has been carried out. The work focuses on accomplishing the energy needs of the building and on designing of an optimal configuration of a solar cooling system. The results of simulation are in terms of thermal loads, solar fraction, energy consumption and economic performance. Italian prices of electricity and natural gas have been considering in order to evaluate economic parameters.

\section{METHODOLOGY}

\subsection{Building heating and cooling demand}

In this work the optimal configuration of a solar cooling and heating system (SCHS) is defined considering: a) solar thermal collectors at low temperatures (FPC collectors) with single effect absorption chiller; b) solar cooling system using high temperature solar thermal collectors (CPC collectors) with multi effect $\left(\mathrm{LiBr}-\mathrm{H}_{2} \mathrm{O}\right)$ absorption chillers.

The SCHS systems were designed to provide the heating and cooling energy demand of building. In addition, the system is designed in order to operate throughout the whole year. Besides, the system has to provide other needs as hot water for a laundry and for bathrooms. 
This work compares three different configurations considering commercially available collectors and absorption chillers:

1. SHCS1

In the SHCS1 configuration, a solar field with flat plate collectors - FPC - and single effect absorption chiller with water as working fluid were used.

\section{2. $\mathrm{SHCS} 2$}

In the SHCS2 configuration, a solar field with evacuated tube collectors - ETC - and single effect absorption chiller with water as working fluid were used.

\section{SHCS3}

In the SHCS3 configuration, a solar field with parabolic trough collectors - PTC - and double effect absorption chiller were used.

Figure 1 shows the sketch of the building simulated. 24 PC workstations, 2 bathrooms and 1 laundry room are in the building.

Energy Plus [29] was used to evaluate thermal loads by machines, people, PC, etc. The maximum thermal load in the summer is in August, as expected, and the requirements of cooling in this month is high because temperatures in this period have high values, so the SHCS is the optimal and an environmentally-friendly solution. The maximum value of the winter thermal load is in January. For FPC and ETC collectors solar radiation on tilted surface is considered whereas for PTC collectors solar radiation on normal surface is considered. For this reason a comparison between three different configurations is possible: for FPC and ETC collectors a solar field oriented to the South and tilted of $40^{\circ}$ from the horizontal is considered; a solar field made with PTC collectors which is oriented to the Est-West to gather the maximum radiation as possible. In Figures 3 and 4 the values of solar radiation on a surface tilted $40^{\circ}$ from the horizontal are shown. To evaluate the normal radiation for PTC collectors the calculation must consider a normal surface to the sun's rays; this is possible only if the surface rotates continuously from East to West conversely.

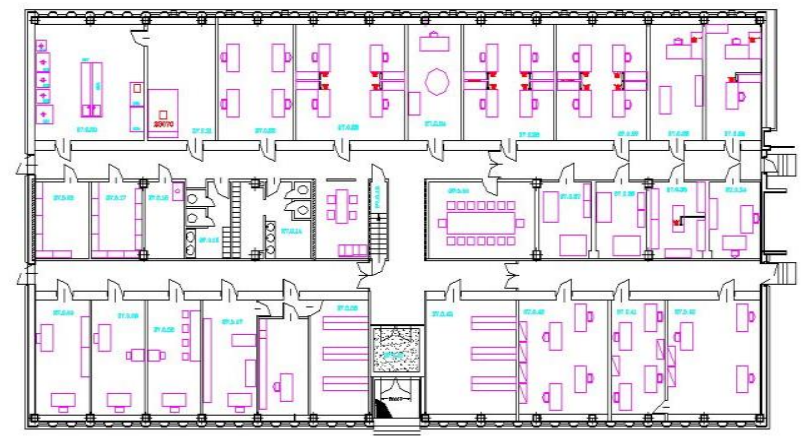

Figure 1. Map of office building

PTC collectors have mirrors with heights between $1.0 \mathrm{~m}$ and $3.0 \mathrm{~m}$ with total lengths ranging between $2.0 \mathrm{~m}$ and 10.0 $\mathrm{m}$. The geometric concentration ratio is between 15 and 20 .

These concentrators are generally oriented in a North South (in this work Est - West) direction and the tracking system is single axis. Fernandez-Garcia et al. [30] presented an overview of the parabolic-trough collectors that have been built during the past. Their work it is a focus on several models commercially available of collectors used in many applications as solar cooling system, pumping irrigation water, solar desalination plants. The receivers are composed of tubes with a diameter between $12 \mathrm{~mm}$ and $50 \mathrm{~mm}$, typically with an outer glass cover. In some cases, between the glass cover and the inner tube a vacuum cavity is inserted in order to limit the thermal dissipations.

The choice of an optimal configuration of a SHCS depends by many factors as:

1. Thermal loads;

2. Available area;

3. Budget;

4. Incentives.

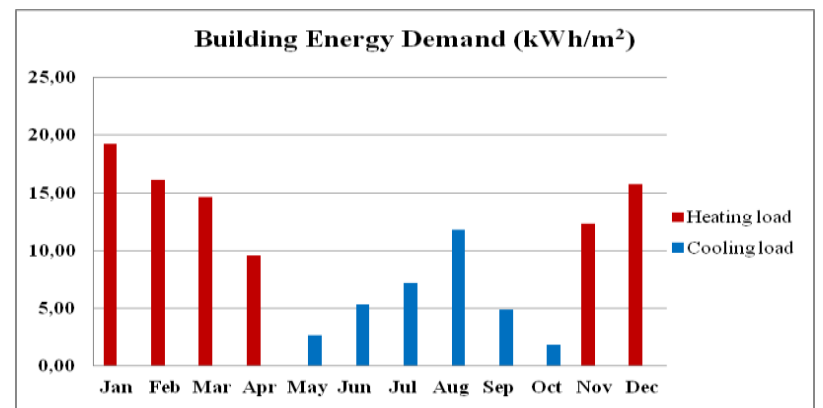

Figure 2. Annual cooling and heating load demand

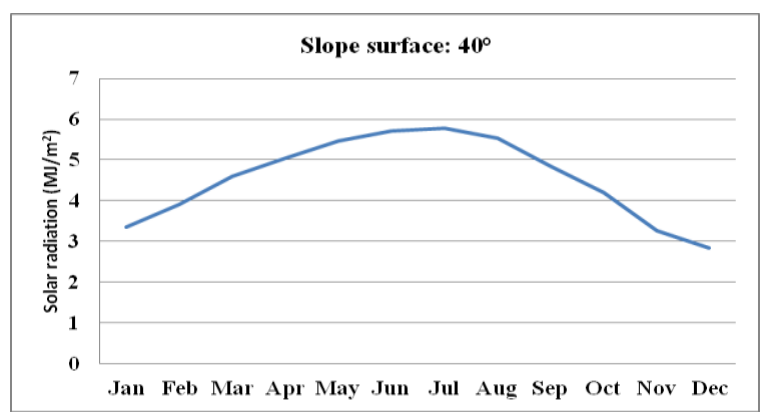

Figure 3. Solar radiation on tilted surface

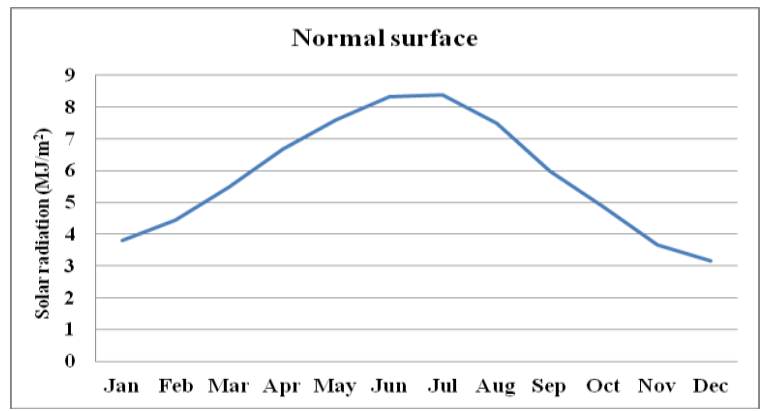

Figure 4. Solar radiation on normal surface

\subsection{Layout and dimensioning of the solar system}

In the present work, the main requisite is the coverage at least of more than $50 \%$ of the annual energy for heating and cooling demand. In addition, the quantity of energy saved using the SHCS in terms of economic and energetic performances is evaluated. Increasing the area occupied by the solar field, the solar fraction increases linearly tending to the unit value but by increasing the solar field area, the cost of the SHCS increases, making not suitable to design the system.

Figure 5 shows the considered SHCS. The solar field and solar thermal collectors are the main components of the SHCS. In addition, other components are: a hot storage tank for the hot water that supplies the double effect absorption chiller; a supplementary boiler which guarantees hot water 
when the solar energy is not enough to heat water; a double effect absorption chiller (the wet cooling tower is built in); a system of fan coils for cooling and heating; valves, pumps and a control system.

Solar fraction and primary energy consumption are essential parameters for the evaluation of the energetic performance of the present SHCS. Solar fraction is defined as the ratio between energy supplied by solar source and the total energy demand required by the building. The other energy sources are electricity and methane. The primary energy consumption corresponding to each configuration is calculated to provide a common expression of all energy sources.

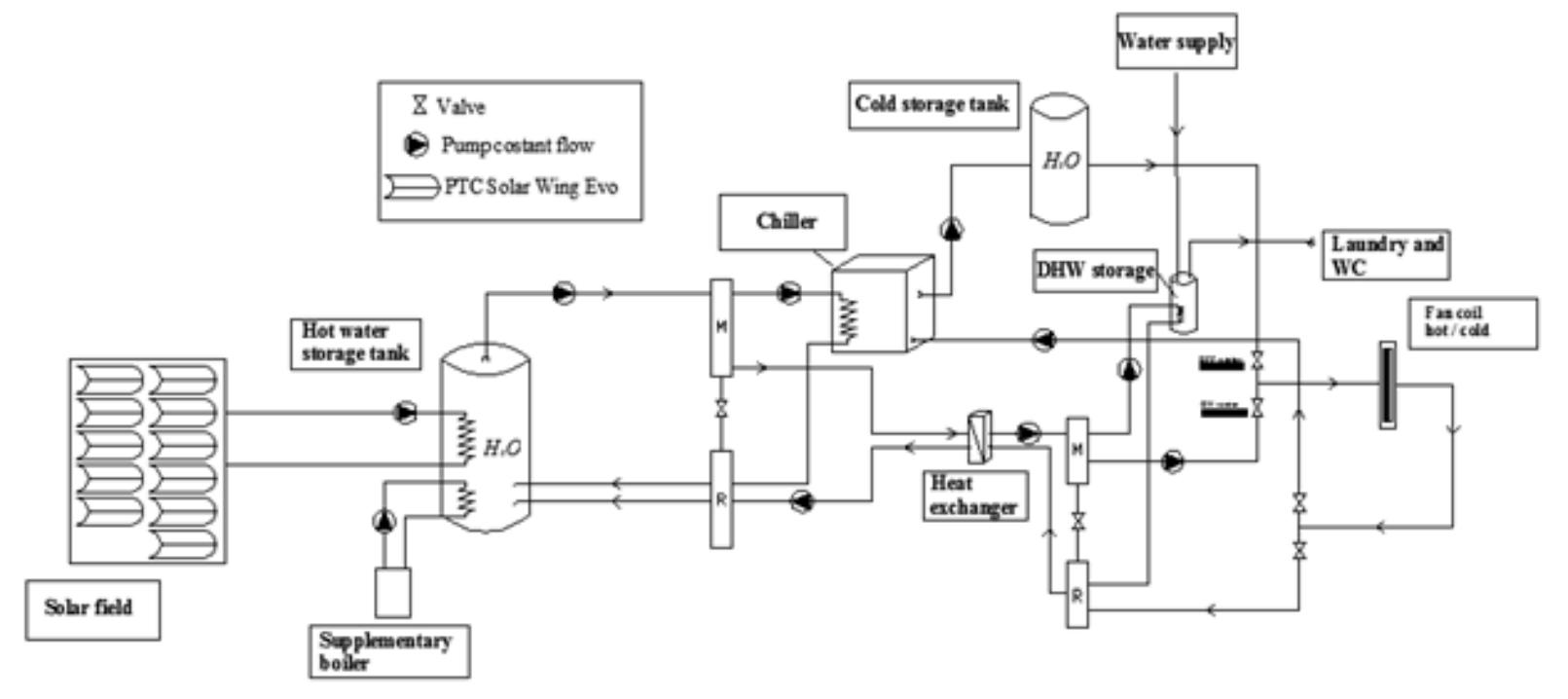

Figure 5. SHCS scheme

The system is considered as a closed cycle system (the heat transfer fluid evolves in a closed cycle). The solar energy from the sun is captured by the solar field, which converts the solar radiation into thermal energy, which is transferred to a refrigeration cycle. Successively, the cold fluid flows toward fan coils for the cooling while the hot fluid flows toward an heat exchanger in order to reduce the temperature useful for DHW (bathroom and laundry) and for heating.

The hot storage tank stores heat produced by the solar field and then provides this to the chiller when it is necessary. A heat exchanger is present in the warm storage tank in such a way the incoming flow from the solar field heats the water in the storage tank. The water, inside the hot storage tank, is pressurized ( 8 bar) because the temperature is maintained at value of $180 \div 200^{\circ} \mathrm{C}$. The cold storage tank has the purpose of introducing a gap, in terms of time, between the production of cold by the absorption chiller and its use for air conditioning. This time difference can be several hours, but can also be of some weeks or even months depending on the case that this is a daily or seasonal storage. The role of the cold storage is also very important during the maintenance time of the absorption machine because it guarantees a cold reserve for many hours.

Table 1. Components of SHCS

\begin{tabular}{lc}
\hline \multicolumn{1}{c}{ Component } & Size \\
\hline Solar Thermal Collectors (PTC) & $90 \mathrm{~m}^{2}$ \\
Hot storage tank & $5 \mathrm{~m}^{3}$ \\
Cold storage tank & $1 \mathrm{~m}^{3}$ \\
DHW tank & $0.5 \mathrm{~m}^{3}$ \\
Chiller & $70 \mathrm{~kW}$ \\
Pumps, valves and control system & - \\
Heat exchanger & - \\
\hline
\end{tabular}

In the present work, the accumulation is daily. However, the cold reserve is used only in the summer time, or when there is demand for cooling, the hot water reserve is used both in the summer time than in the winter time, because the laundry and bathrooms need warm water during throughout the year. When the thermal energy from the sun, and, therefore the solar field, is not sufficient to meet demand during critical periods, an auxiliary boiler is needed. This auxiliary boiler guarantees that warm water, both for the warm storage tank and for the absorption chiller machine, is always available.

\section{3. "NEGST" TOOL}

NEGST [31] was a product of a European project. The overall objective of this project is to introduce more costeffective solar thermal systems, particularly for domestic hot water preparation and/or space heating, to the market in order to contribute to the European Union's Action Plans with regard to the reduction of $\mathrm{CO}_{2}-$ Emissions and the cost effective supply of renewable energies. In order to achieve this goal the project provides a framework for the development of the next generation of solar thermal systems and their introduction to the market.

\section{ANALYSIS}

The thermal analysis on three different solar cooling systems configurations was performed by defining the following main steps:

Evaluation of both cooling and heating loads on monthly basis for the building located in the Mediterranean area;

Evaluation of the primary energy consumption of the conventional cooling and heating system with electricity and methane. An electrically driven vapour compression chiller, 
operating as a heat pump during the winter season, is assumed as the default reference system;

Evaluation of the thermal energy required by the SHCS;

Minimal aim for the fraction of the primary energy consumption to be replaced by the SHCS;

Evaluation of the solar field area to obtain the desired primary energy saving.

In the present work the SHCS was designed with characteristics shown in Table 2.

Figure 6 shows the "Reference CHP", coefficient of performance values of heat pump values in compression, for the heating system (Heating COP), and for the cooling system (Cooling COP). The heating and cooling COP of a reference heating and cooling system have to be provided (the default values correspond to the average heating and cooling COP of an electrically driven vapor compression heat pump). This issue allows evaluating the corresponding primary energy consumed by the heating and cooling machine assumed as the reference system.

Table 2. Collectors' parameters

\begin{tabular}{|c|c|c|c|c|}
\hline Parameter & Unit & FPC & ETC & PTC \\
\hline Area & $\mathrm{m}^{2}$ & 2.20 & 3.31 & 8.25 \\
\hline Collector azimuth & $\circ$ & 0 & 0 & 0 \\
\hline Collector orientation & - & South & South & E-W \\
\hline Concentration ratio & - & - & - & 60 \\
\hline Collector slope & $\circ$ & 40 & 40 & - \\
\hline$\eta_{0}$ & - & 0.78 & 0.72 & 0.72 \\
\hline$c_{1}$ & $\mathrm{~W} / \mathrm{m}^{2} \mathrm{~K}$ & 3.88 & 1 & 0.60 \\
\hline$c_{2}$ & $\mathrm{~W} / \mathrm{m}^{2} \mathrm{~K}^{2}$ & 0.011 & 0.005 & 0 \\
\hline
\end{tabular}

The solar field surface is equal to $90 \mathrm{~m}^{2}$ for all configurations described in this work; then, it is evaluated the solar fraction. Besides, it has assumed that the solar field is acceptable to determine a coverage greater than $60 \%$ of the demand of the energy for cooling and heating. To guarantee an availability of hot water for at least six hours and to respect the percentage of $60 \%$ it has been necessary to include in the SHCS a warm storage tank of $5.0 \mathrm{~m}^{3}$. The hot storage tank for DHW has designed considering the warm water demand for toilets and the liters required for the washing of each washing machine present in the laundry. The solar field is extended with $5.0 \mathrm{~m}^{2}$ of solar collectors to have a right proportion between the solar field and the amount of accumulated water in the tanks.

A single effect absorption chiller is used in the configuration 1 (SHCS1) and configuration 2 (SHCS2). Single effect absorption chiller is the right solution because the temperature reached by the evacuated tube collectors is greater than that attainable from the flat plate collectors, but still falling within the range $70-100^{\circ} \mathrm{C}$, values compatible with those suitable for a correct operation of a chiller single effect. For the configuration 3 (SHCS3), a double effect chiller lithium bromide - water $(70 \mathrm{~kW})$ as shown in Figure 7 is compatible with the PTC collectors. This choice is motivated in that typical double effect machines require heat transfer fluids at high inlet temperatures (around $140-180^{\circ} \mathrm{C}$ ), and the parabolic collectors (PTC) can easily reach these temperatures. A comparison between the three different configurations has been carried out. It has been possible to choose one, and carry out on a second time design considerations to achieve economic and financial analysis.

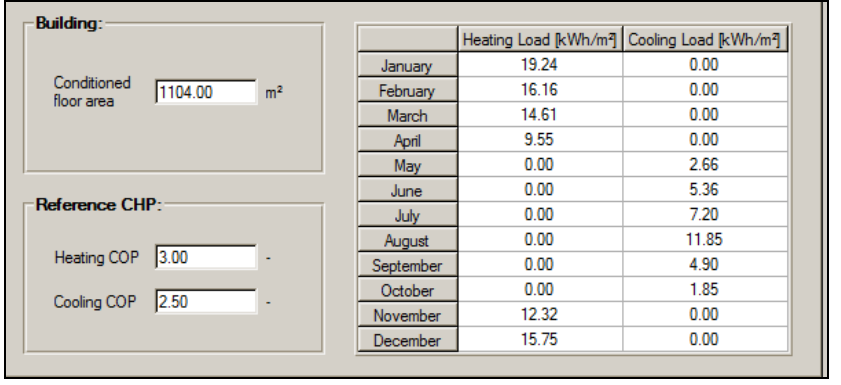

Figure 6. Input data with NEGST

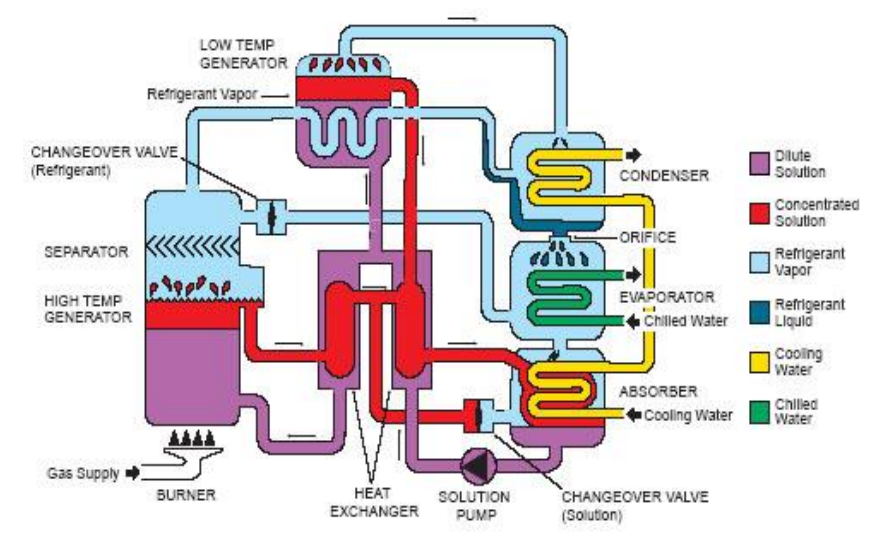

Figure 7. Double effect absorption chiller (cooling)

Table 3. Results of SHC3 system

\begin{tabular}{|l|l|l|l|l|l|}
\hline Month & $\begin{array}{l}\mathrm{S}_{\mathrm{rt}} \\
(k W h)\end{array}$ & $\begin{array}{l}\mathrm{H}_{\mathrm{L}} \\
(k W h)\end{array}$ & $\begin{array}{l}\mathrm{C}_{\mathrm{L}} \\
(k W h)\end{array}$ & $\begin{array}{l}\mathrm{Th}_{\mathrm{S}} \\
(k W h)\end{array}$ & $\mathrm{f}-$ \\
\hline January & 26396.86 & 19240 & 0 & 19240 & 0.39 \\
\hline Febraury & 18028.59 & 16160 & 0 & 16160 & 0.42 \\
\hline March & 16340.63 & 14610 & 0 & 14610 & 0.57 \\
\hline April & 14543.77 & 9550 & 0 & 9550 & 0.91 \\
\hline May & 17534.78 & 0 & 2660 & 2418.18 & 1 \\
\hline June & 19333.23 & 0 & 5360 & 4872.73 & 1 \\
\hline July & 20476.69 & 0 & 7200 & 6545.45 & 1 \\
\hline August & 18481.72 & 0 & 11850 & 107772.7 & 1 \\
\hline September & 15646.87 & 0 & 4900 & 4454.55 & 1 \\
\hline October & 18892.09 & 0 & 1850 & 1681.82 & 1 \\
\hline November & 20180.56 & 12320 & 0 & 12320 & 0.5 \\
\hline December & 21870.45 & 15750 & 0 & 15750 & 0.36 \\
\hline
\end{tabular}

\section{RESULTS AND DISCUSSION}

\subsection{System performance}

All the configurations have been analyzed throughout the year. Primary energy and solar fraction are the parameters to define the right configuration, so as shown in Table 4. 
Table 4. Annual analysis

\begin{tabular}{ccccc}
\hline & $\begin{array}{c}\text { PE-CHP } \\
{[\mathrm{kWh}]}\end{array}$ & $\begin{array}{c}\text { PE-consumed } \\
{[\mathrm{kWh}]}\end{array}$ & $\begin{array}{c}\text { PE- } \\
\text { saving } \\
{[\%]}\end{array}$ & $\begin{array}{c}\mathrm{f} \\
{[-]}\end{array}$ \\
\hline$F P C$ & 106845.00 & 90031.64 & $16 \%$ & 0.40 \\
$E T C$ & 106845.00 & 44517.64 & $58 \%$ & 0.71 \\
$P T C$ & 106845.00 & 49442.70 & $54 \%$ & 0.62 \\
\hline
\end{tabular}

"PE-CHP" are the primary energy consumptions of the reference system, "PE-Consumed" is the consumed primary energy of the back-up unit and $f$ the average solar fraction in the year. Table 4 considers the comparison of the yearly solar fraction that is obtained from the configurations of systems SHCS1, SHCS2, SHCS3. In fact, the three histograms in Figures 8-10 show the evolution of the annual solar fraction each month. The trend of the solar fraction for all configurations is shown. A solar field with ETC collectors have better performances than one with FPC collectors in terms of annual solar fraction evaluated with the NEGST tool. Evacuated tube collectors have an essential characteristic: the presence of vacuum sealing gap. This factor is important in terms of seasonal efficiency because the gap allows a high reduction of the thermal losses by convection and conduction. For the configuration SHCS2 the effect of the inclination of the solar field on the annual solar fraction, Figure 9, is calculated. The preferable inclination angle from the horizontal has been estimated equal to $40^{\circ}$, as shown in Figure 11 . Considering annual performances, the ETC collectors have a value of solar fraction equal to 0.71 ; in the summer time, they have a moderately low value of $f$, particularly in the months of July and August (0.71 and 0.48 respectively). A solar field with FPC collectors has a low annual efficiency, in fact a solar field of $90 \mathrm{~m}^{2}$ can annually reach a solar fraction value equal to 0.40 , Fig. 8 . This means that the remaining energy demand by the building must be provided by supplementary boiler. The configuration SHCS3 is particularly interesting. In a system with ETC collectors, the boiler have to work in the summer months to integrate the absorption cooling machine while, in a system with PTC collectors, the supplementary boiler can even be switched off throughout the period from May to October, which are the months when there is a unitary solar fraction.

In the Mediterranean Area the demand of electricity for cooling in the summer time is very high, then, it is necessary to design a system capable to reduce the consumption of primary energy for cooling.

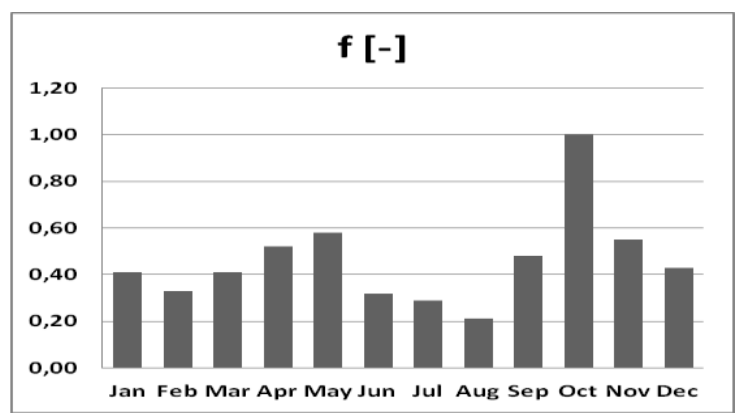

Figure 8. Solar fraction for system SHCS1

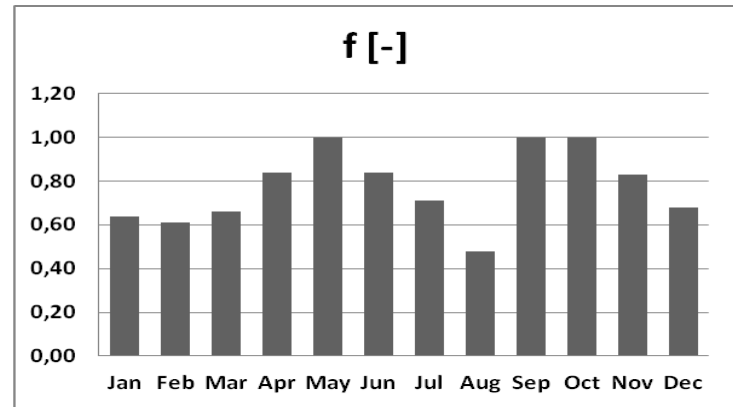

Figure 9. Solar fraction for system SHCS2

Configuration SHCS 3 has all characteristics to reach this aims. In fact, they could offer their best just when the radiation is greater, that is during the summer. For SHCS3 solar fraction is equal to 0.62 , Figure 10 . This implies a $54 \%$ of primary energy saved in comparison with a conventional system that consists of a heat pump electrically powered (vapor compression chiller), which is active in both winter and summer. The optimal solar field is shown in Table 5.

The energy required by the supplementary boiler and the solar energy evolved by solar system are shown in Figure 12.

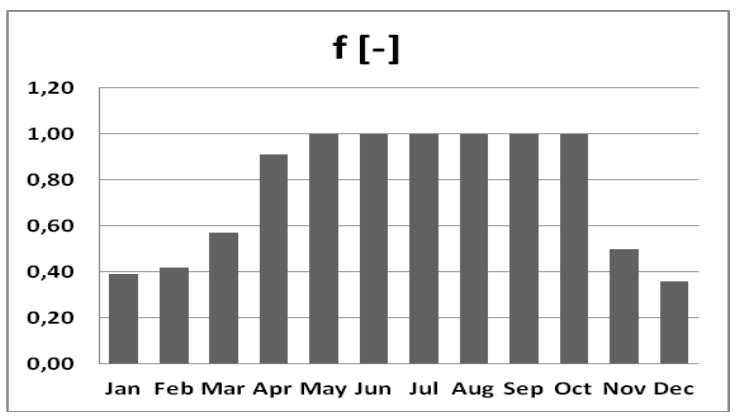

Figure 10. Solar fraction for system SHCS3

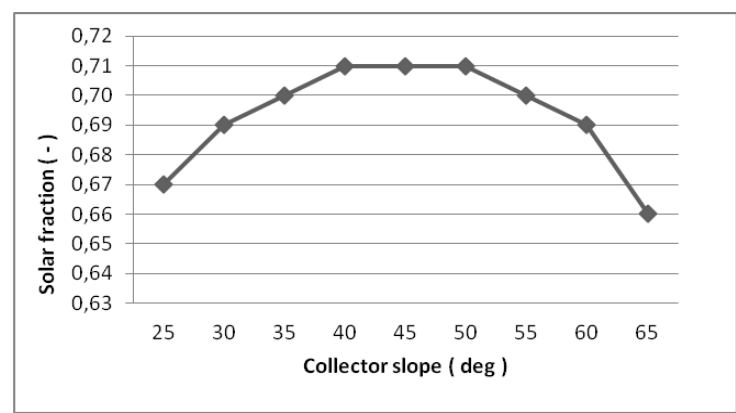

Figure 11. Solar fraction at different collector slope

Table 5. Optimal solar field

\begin{tabular}{llcc}
\hline $\begin{array}{l}\text { Solar field } \\
{\left[\mathrm{m}^{2}\right]}\end{array}$ & $\begin{array}{l}\text { PE-CHP } \\
{[\mathrm{kWh}]}\end{array}$ & $\begin{array}{c}\text { PE-saving } \\
{[\mathrm{kWh}]}\end{array}$ & $\begin{array}{c}\text { PE-saving } \\
{[\%]}\end{array}$ \\
\hline 70 & 106845 & 44874.90 & 42 \\
80 & 106845 & 51285.60 & 48 \\
90 & 106845 & 57696.30 & 54 \\
100 & 106845 & 61970.10 & 58 \\
\hline
\end{tabular}

\subsection{Economic analysis}

The optimal configuration of SHCS is that with parabolic through collectors. The feasibility study has made to evaluate the economic sustainability of the solar heating and cooling plant, then an economic analysis is carried out on the SHCS 3 
configuration taking into account both capital and operating costs of the system. The more expensive parts of the SHCS are solar field and absorption cooling machine (38000 $€$ and $25000 €$ respectively), other components have negligible effects. For the economic evaluation of the system the energy prices met Italy in fall 2015 were used. The remuneration for thermal energy was based on commercially valid prices. Overall the plant has an initial cost of 98,000.00€, which coincides with the initial investment. To assess the economic feasibility of the plant, an estimation of the annual cost savings, cash flows accumulated, the payback period must be carried out. The following table shows some financial data, including the annual savings in euro, achieved thanks to the construction of the plant. Furthermore, it is essential to consider the annual maintenance and electricity consumption related to the electric pumps, the chiller and control devices. Therefore, this consumption represent an expense that must be addressed in any case every year, but that does not involve serious cash outflow.

Table 6. Economic parameters

\begin{tabular}{lcc}
\hline Investment & $98,000.00$ & $€$ \\
Incentive & $76,500.00$ & $€$ \\
Energy cost before SHCS & $17,095.20$ & $€ /$ year \\
Energy cost after SHCS & $1,691.20$ & $€ /$ year \\
Hi (Methane) & 9.94 & $\mathrm{kWh} / \mathrm{Nm}^{3}$ \\
Fuel price & 0.34 & $€ / \mathrm{m}^{3}$ \\
Annual money savings & $15,404.00$ & $€ /$ year \\
Annual maintenance & $2,600.00$ & $€ /$ year \\
Fuel inflation rate & 3.50 & $\%$ \\
Interest rate & 5.00 & $\%$ \\
General inflation rate & 3.00 & $\%$ \\
\hline
\end{tabular}

Many incentives are present in Italy for the development of energy from sun and in general from renewable sources. Each incentive changes in function of the type of plant. The incentive is expressed in years. In the present work, the incentive time is five years. The project provides that the only one energetic source is natural gas for the supplementary boiler. The annual savings in euro has been assessed as the difference between the cost of primary energy before and after the project. The difference is equal to $15,404 €$ and it is the cost savings achieved at the end of the first year of investment, then, considering the fuel inflation rate, it is estimated the actual cost savings, year by year.

The ratio between the initial investment and cash flows is the payback period. Clearly, the lower the value of the payback the lower the investment risk since it would require less time to recover the money invested. Net present value (NPV) and Internal Rate of Return (IRR) have been evaluated. NPV represents the profit generated by the investment, expressed in money; IRR is the return offered by the project, evaluated on the initial outlay based on cash flows in future periods.

The values reported in Table 7 are referred to an analysis conducted to twenty and twenty-five years. Figure 14 shows the payback period is 3.4 years and the NPV increases linearly with the years.

Furthermore, an evolution of costs for Photovoltaic (PV) panels that drive a compressor chiller has been carried out. For building thermal gains in the whole cooling season a 100 $\mathrm{kWp}$ PV field is needed. Only the PV field would cost about $100,000.00 €$. Therefore, the investments for solar thermal and PV driven cooling systems are comparable but a solar thermal system provides also both heat to the building in the cold season and domestic hot water.

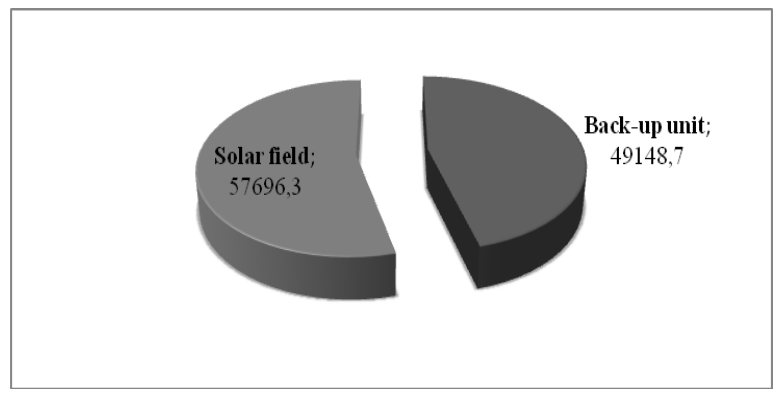

Figure 12. Primary energy savings

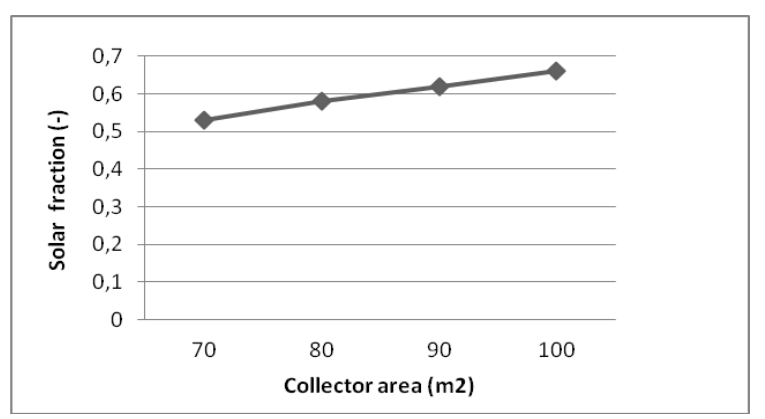

Figure 13. Solar fraction at different collector's surface

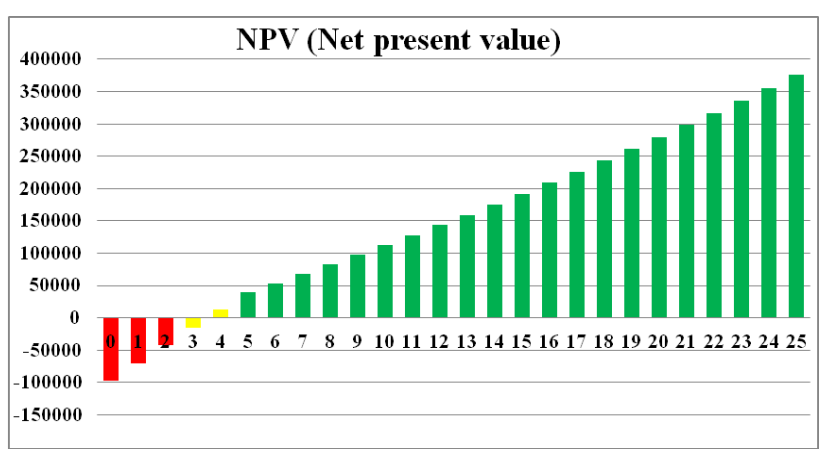

Figure 14. NPV estimated to twenty-five years

Table 7. Parameters related economic financial analysis

\begin{tabular}{lcc}
\hline NPV (Net Present Value) & $€ 279,805.40$ & $€ 375,689.09$ \\
IRR (Internal Rate Return) & $25.9 \%$ & $26.1 \%$ \\
PBT (Pay Back Time) & 3.4 & 3.4 \\
\hline
\end{tabular}

\section{CONCLUSIONS}

The present work focused on the feasibility study of a solar heating and cooling system. The solar field occupies an area of $95 \mathrm{~m}^{2}$ (divided into $90 \mathrm{~m}^{2}$ for the cooling and heating demand and into $5.0 \mathrm{~m}^{2}$ for domestic hot water) and different storage tanks are present: $0.50 \mathrm{~m}^{3}$ for DHW, $5.00 \mathrm{~m}^{3}$ for the hot water (heating and for absorption cooling machine) and $2.00 \mathrm{~m}^{3}$ for cold water (reserve of cold water). A supplementary boiler of $35 \mathrm{~kW}$ is present. Fan coils are the terminal part of the system, which cool in summer and warm in winter by using a simple and reliable technology based right on the water as the heat transfer fluid.

Main conclusions of this work are: 
- In the summer analysis, the PTC collectors are more efficient than ETC and FPC collectors because the supplementary boiler does not work in the summer months allowing a minimal consumption of electricity for air conditioning.

- In the winter analysis the ETC collectors are more efficient than PTC and FPC (PE-saving equal to 58\%) because the solar fraction are higher for the winter months.

In the Mediterranean Area the energy required is overall for air conditioning in the summer months, so the optimal configuration is a SHCS with PTC and double effect absorption chiller.

\section{REFERENCES}

[1] Solar cooling position paper. Task 38 solar airconditioning and refrigeration, from http://task38.ieashc.org/data/sites/1/publications/IEA-SHC-SolarCooling-Position-Paper.pdf, accessed on day 09 March 2017.

[2] State of the art for solar thermal or PV cooling and refrigeration. Task 53 new generation solar cooling and heating systems (PV or solar thermally driven systems), from http://task53.ieashc.org/data/sites/1/publications/SHC-2014--

Mugnier--Solar-Cooling.pdf, accessed on day 09 March 2017.

[3] Perdichizzi A., Birigozzi A., Franchini G., Ravelli S. (2015). Peak shaving strategy through a solar combined cooling and power system in remote hot climate areas, Applied Energy, Vol. 143, pp. 154-63. DOI: $10.1016 /$ j.apenergy.2015.01.030

[4] Mazloumi M., Naghashzadegan M., Javaherdeh K. (2008). Simulation of a solar lithium bromide water absorption cooling system with parabolic through collector, Energy Conversion and Management, Vol. 49, No. 10, pp. 2820-2832. DOI: 10.1016/j.enconman.2008.03.014

[5] Assilzadeh F., Kalogirou S.A., Ali Y., Sopian K. (2008). Simulation and optimization of a $\mathrm{LiBr}$ solar absorption cooling system with evacuated tube collectors, Renewable Energy, Vol. 45, No. 8, pp. 1143-59. DOI: $10.1016 /$ j.renene.2004.09.017

[6] Praene J.P., Marc O., Lucas F., Miranville F. (2011). Simulation and experimental investigation of solar absorption cooling system in Reunion Island, Applied Energy, Vol. 88, pp. 831-839. DOI: 10.1016/j.apenergy.2010.09.016

[7] Fong K.F., Lee C.K., Chow T.T. (2012). Comparative study of solar cooling system with building-integrated solar collectors for use in sub-tropical regions like Hong Kong, Applied Energy, Vol. 90, pp. 189-195. DOI: 10.1016/j.apenergy.2011.06.013

[8] Molero-Villar N., Cejudo-Lopez J.M., DominguezMu-noz F., Carillo-Andres A. (2012). A comparison of solar absorption system configurations, Solar Energy, Vol. 86, pp. 242-252. DOI: 10.1016/j.solener.2011.09.027

[9] Sarabia Escriva E.J., Lamas Sivila E.V., Soto Frances V.M. (2011). Air conditioning production by a single effect absorption cooling machine directly coupled to a solar collector field. Application to Spanish climates, Solar Energy, Vol. 85, pp. 2108-2121. DOI: $\underline{10.1016 / j . s o l e n e r .2011 .05 .019}$
[10] Casals X.G. (2006). Solar absorption cooling in Spain: perspectives and outcomes from the simulation of recent installations, Renewable Energy, Vol. 31, No. 9, pp. 1371-1389. DOI: 10.1016/j.renene.2005.07.002

[11] Evola G., Le Pierrès Z., Marletta L.G. (2015). Simulation of a low capacity absorption cooling system for indoor air-conditioning, International Journal of Heat and Technology, Vol. 33, No. 4, pp. 203-210. DOI: 10.18280/ijht.330427

[12] Luna A. (2008). Diseno y evaluacion de vivienda energeticamente sustentable, PhD dissertation, Universidad Autonoma de Baja California, Mexicali, Mexico.

[13] Florides G.A., Kalogirou S.A., Tassou S.A., Wrobel L.C. (2002). Modelling and simulation of an absorption solar cooling system for Cyprus, Solar Energy, Vol. 72, No. 1, pp. 43-51. DOI: 10.1016/S0038-092X(01)00081-0

[14] Calise F., Palombo A., Vanoli L. (2012). Design and dynamic simulation of a novel polygeneration system fed by vegetable oil and by solar energy, Energy Conversion and Management, Vol. 60, pp. 204-213. DOI: $10.1016 /$ j.enconman.2012.02.014

[15] Tienerney M.J. (2007). Options for solar-assisted refrigeration-through collectors and double-effect chillers, Renewable Energy, Vol. 32, No. 2, pp. 183199. DOI: $10.1016 /$ i.renene.2006.01.018

[16] Said S.A.M., El-Shaarawi M.A.I., Siddiqui M.U. (2015). Analysis of a solar powered absorption system, Energy Conversion and Management, Vol. 97, pp. 243-252. DOI: 10.1016/j.enconman.2015.03.046

[17] Balghouthi M., Chahbani M.H., Guizani A. (2008). Feasibility of solar absorption air conditioning in Tunisia, Building and Environment, Vol. 43, No. 9, pp. 1459-1470. DOI: 10.1016/j.buildenv.2007.08.003

[18] Reda F., Viot M., Sipila K., Helm M. (2016). Energy assessment of solar cooling thermally driven system configurations for an office building in a Nordic country, Applied Energy, Vol. 166, pp. 27-43. DOI: 10.1016/j.apenergy.2015.12.119

[19] Shirazi A., Taylor R.A., White S.D., Morrison G.L. (2016). A systematic parametric study and feasibility assessment of solar-assisted single-effect, doubleeffect, and triple-effect absorption chillers for heating and cooling applications, Energy Conversion and Management, Vol. 114, pp. 258-277. DOI: 10.1016/j.enconman.2016.01.070

[20] Al-Alili A., Islam M.D., Kubo I., Hwang Y., Radermacher R. (2012). Modeling of a solar powered absorption cycle for Abu Dhabi, Applied Energy, Vol. 93, pp. 160-167, DOI: 10.1016/j.apenergy.2010.11.034

[21] Mammoli A., Vorobieff P., Barsun H., Burnett R., Fisher D. (2010). Energetic, economic and environmental performance of a solar-thermal-assisted HVAC system, Energy and Buildings, Vol. 42, No. 9, pp. 1524-1535. DOI: $10.1016 /$ j.enbuild.2010.03.023

[22] Eicker U., Colmenar-Santos A., Teran L., Cotrado M., Borge-Diez D. (2014). Economic evaluation of solar thermal and photovoltaic cooling system through simulation different climatic conditions: an analysis in three different cities in Europe, Energy and Buildings, Vol. 70, pp. 207-223. DOI: 10.1016/j.enbuild.2013.11.061 
[23] Eicker U., Pietruschka D., Haag M., Schmitt A. (2015). Systematic design and analysis of solar thermal cooling systems in different climates, Renewable Energy, Vol. 80, pp. 827-36. DOI: $\underline{10.1016 / \text { j.renene.2015.02.019 }}$

[24] Eicker U., Pietruschka D., Haag M., Schmitt A. (2015). Comparison of photovoltaic and solar thermal cooling systems for office buildings in different climates, Solar Energy, Vol. 118, pp. 243-255. DOI: 10.1016/j.solener.2015.05.018

[25] Cucumo M., Ferraro V., Kaliakatsos D., Marinelli V. (2013). A calculation model for a thermodynamic analysis of solar plants with parabolic collectors cooled by air evolving in a open Joule-Brayton cycle, International Journal of Heat and Technology, Vol. 31, No. 2, pp. 127-134. DOI: 10.18280/ijht.310217

[26] Regue M.H., Benchatti T., Medjelled A., Benchatti A. (2014). Improving the performances of a solar cylindrical parabolic dual reflection Fresnel mirror (Experimental part), International Journal of Heat and Technology, Vol. 32, No. 1-2, pp. 171-178.

[27] Drosou V., Kosmopoulos P., Papadopoulos A. (2016). Solar cooling system using concentrating collectors for office buildings: a case study for Greece, Renewable Energy, Vol. 97, pp. 697-708. DOI: 10.1016/j.renene.2016.06.027

[28] Sibilio S., Ciampi G., Rosato A., Entchev E., Yaici W. (2016). Parametric analysis of a solar heating and cooling system for an Italian multi-family house, International Journal of Heat and Technology, Vol. 34, Special Issue 2, pp. S458-S464. DOI: $\underline{10.18280 / \text { ijht. } 34 \text { S238 }}$

[29] EnergyPlus-Energy Simulation Software, from http://apps1.eere.energy.gov/buildings/energyplus/, accessed on day 09 March 2017

[30] Fernandez-Garcia A., Zarza E., Valenzuela L., Perez M. (2010). Parabolic-trough solar collectors and their applications, Renewable and Sustainable Energy Reviews, Vol. 14, No. 7, pp. 1695-1721. DOI: 10.1016/j.rser.2010.03.012.

[31] NEGST-New Generation of Solar Thermal Systems, from http://www.swt-technologie.de/html/negst.html, accessed on day 09 March 2017.

\section{NOMENCLATURE}

$\mathrm{c}_{1}$

$\mathrm{c}_{2}$

$\mathrm{C}_{\mathrm{L}}$

ETC

f

FPC

$\mathrm{H}_{\mathrm{L}}$

PE

PTC

SHCS

$\mathrm{S}_{\mathrm{rt}}$

$\mathrm{T}_{\mathrm{hs}}$

\section{Greek symbols}

$\eta_{0}$
Collector's coefficient $\left(\mathrm{W} / \mathrm{m}^{2} \mathrm{~K}\right)$

Collector's coefficient $\left(\mathrm{W} / \mathrm{m}^{2} \mathrm{~K}^{2}\right)$

Cooling load (kW h)

Evacuated tube collector

Solar fraction

Flat plate collector

Heating load (kWh)

Primary energy (kW h)

Parabolic through collector

Solar heating and cooling system

Solar radiation on tilted surface $(\mathrm{kW} \mathrm{h})$

Thermal load required ( $\mathrm{kW} \mathrm{h}$ )

Collector's efficiency 